\title{
The Role of the Blue Economy in National Development: A Case of Ghana
}

\author{
Article by Benjamin Ashitey Amarh \\ Texila American University, Guyana \\ E-mail: amarh_benjamin@yahoo.com
}

\begin{abstract}
This assessment paper give emphasis to the contributions of the blue economy to national development. It stresses the point that the blue economy has great impact on a nation's development. This actually explains why recent governments of various countries has given much attention and focus on their marine boundaries expecting to use it among others, as a mechanism of safe guarding their territorial waters with consequential hope of discovering natural minerals like oil which will help in enhancing the national resources used in developing the lives of their citizenry in terms of standard of living and the general development of the nation. This is because, the blue economy, in the life of a nation, provides great advantage in terms of the economic development of that country and a great disadvantage to the land lock nations at the back-dropped of the fact that the blue economy has long been an economic force to reckon with. It is also used by nations as the force and wall of their national defense and it has been observed that it plays major role in the international trade of the country. Looking at the blue economy in this perspective demands for proper attention from central government, traditional authorities, and the public and local governments to make sure that, this God-given treasure do not become a national curse but would be put to efficient use to produce the anticipated results, which will encourage national development. As valuable as it is, the blue economy is being muddled up in Ghana as the resource suffers from pollution as a result of scientific fishing, pollution by the public and by illegal miners and these calls for the need for better ocean governance. This study intends to achieve the following objectives; first is to determine the role and benefit of the blue economy in national development, to identify some challenges faced in the management of the blue economy of Ghana and to determine and make effective recommendations that would aid to reduce or mitigate the challenges faced by the blue economy. To achieve the objectives slated for this paper, review of secondary data from documented reports and the internet, publications, journals and articles were used. The primary data was an in-depth guided interview with key informants (fishing folk, oil and gas officers, port management and shipping officers etc.) and observation of events relating to the sea. To make the nation derive maximum dividends from the blue economy, valuable recommendations were offered.
\end{abstract}

Keywords: Blue Economy, National Development, Marine, Ocean, Ghana.

\section{Introduction}

The blue economy is a vital area in any nation that is blessed to possess the resource. Being a major asset to a nation and a major investment in national development, it plays a critical role in the productivity and growth of a nation. According to Dr. Christian Bueger (2016), the Blue economy emphasizes the economic potential of ocean resources, ranging from fishing, natural resource extraction, to tourism. The blue economy is not only about economic growth, but also about the importance of striking a balance between blue growth, ocean health, and sustainability. Nevertheless, the ocean economy has not been given the needed recognition that it deserves especially in the coastal African countries where most natural resources are taken for granted. Perhaps, this is so because of the in height ignorance of the people or the degraded recognition of its importance to the nation. In the Ghanaian circumstance, for the blue economy to contribute meaningfully to national development, there should be proper and adequate policy regulation, serious investment in maritime security and enough funding to facilitate the protection and security of the territorial oceans. If this is done in the proper way, only then the great potentials of the blue economy can be tapped and explored and the sector will contribute meaningfully to national development. A careful observation of the blue economy reveals 
the sea's immense treasure through assessments of goods and services ranging from fisheries to coastal storm protection that contributes greatly to national development. There is also the need to mention that there are inexorable attack on ocean resources through over-exploitation, mistreatment and climate change. Notwithstanding the above observation, the central focus of this paper remains the contributions of the blue economy to national development.

\section{Conceptual clarifications}

In this paper, there are certain concepts like blue economy and national development, which need clarification. Gunter Pauli's book, "The Blue Economy: 10 years, 100 innovations, 100 million jobs" (2010) brought the Blue Economy concept into prominence. The Blue Economy is envisaged as the integration of Ocean Economy development with the principles of social inclusion, environmental sustainability and innovative, dynamic business models. In WWF's view, there remains no specific definition of the blue economy and fears the ambiguity may pose a danger. The WWF went on to state that "For some, blue economy means the use of the sea and its resources for sustainable economic development," and "For others, it simply refers to any economic activity in the maritime sector, whether sustainable or not." Thus, the principles have been developed to "fill this gap in shared understanding about what characterizes istepa sustainable blue economy, and to help ensure that the economic development of the ocean contributes to true prosperity, today and long into the future..." A first working definition by Catherine Piante/WWF-France (2013), (based on SIDS Concept Paper) stated that, the "Blue Economy" is marine-based economic development that leads to improved human wellbeing and social equity, while significantly reducing environmental risks and ecological scarcities. It includes:

- Reframing the oceans as "Development Spaces" that are subject to spatial planning.

- Making use of that planning to integrate "conservation, sustainable use, oil and mineral wealth extraction, bio-prospecting, sustainable energy production and marine transport".

- Incorporating the value of the oceans into economic decision-making.

- Establishing policies that favor low-carbon, resource-efficient, and socially inclusive development (mirroring the Green Economy framework in this regard).

- Prioritizing the use of the seas to benefit people, alleviate poverty, generate employment, and promote equity.

- Decoupling socio-economic development from environmental degradation.

- Improving relevant international law and governance mechanisms.

From, the above definition, the researcher opted to define blue economy as an economy that aims at diminishing or eradicating of oceanic environmentally friendly dangers to encourage sustainable development of dependent communities or nations without mortifying the oceanic locality. It is an economy that supports the friendly interaction between living beings and the marine environment with the consequential benefit both to the people and to the marine environment.

The other concept to clarify here is national development. According to the Cambridge English Dictionary, development is the process in which someone or something grows or changes and becomes more advanced. Martin \& Ayman (2017) further explained development as the transformation of community into socially, economically, politically, educationally, orderly, and materially desirable conditions, with the aim of improving the quality of life of the people. It is also referred to as the uniform distribution of resources, the integration of the people into national economy; it is a socio-economic process, which seeks to bring about a more equitable distribution of resources and income within the society. Developed nations are often classified based on their economic growth. Thomas M. Leonard (2006) stressed the assumption that, developed nations are representative democracies where the rights of people are guaranteed, basic human needs are satisfied and the environment secured from various forms of pollution. UNESCO (2000) also defined national development as the ability of a county to improve the social welfare of the people e.g. by providing social amenities like quality education, potable water, transportation infrastructure, medical care, etc. National development can also be described as the overall development or a collective socio-economic, political as well as religious advancement of a country or nation. This is best achieved through development planning, which can be 
described as the country's collection of strategies mapped out by the government. (Tolu Lawal and Abe Oluwatoyin, 2011). National development can therefore be said to refer to the capability of a nation to improve and develop the lives of its people to be able to contribute their quota in all sectors of the economy.

\section{Contribution of the blue economy to national development}

\section{Employment creation}

The focus of this study is to gaze at the contributions of the blue economy to national development, which can be a catalyst for every nation's wellbeing and fortune. Noticeable among the opinions to be considered here is that, the blue economy creates and generates employment. The number of people who earns a living on the blue economy cannot be underestimated and ignored. It cuts across so many sectors like fisheries, oil and gas, shipping and so on and so forth. According to the European Commission staff-working document on blue growth report 2015, Europe's maritime sector employs over five (5) million jobs generating almost EUR 500 billion a year, with a potential to create many more jobs. Offshore renewable energy is now a major contributor to employment, accounting for 150,000 jobs. The story of Ghana and to large extent Africa is no difference as the blue economy has created quite a number of jobs to its citizenry. The sectors of the blue economy comprises of fisheries, ports, aquaculture, tourism, transport, coastal mining, and energy. It has breed anglers, fishmongers, traders in fishing gears, oil and gas officers, shipping clerks, seamen, seafood processing companies and the likes. The Organization for Economic Co-operation and Development (OECD) predicts that looking to 2030; many ocean-based industries have the potential to outperform the global economy as a whole, both in terms of value added and employment.

\section{Facilitation of trade and commerce}

Another contribution to national development by the blue economy is the facilitation of trade and commerce. The blue economy facilitates the movements of goods and services from the manufacturer to the intended market giving value to such goods and services. The blue economy is the provider of convenient transport routes in logistics. Ships carry around $90 \%$ of all trade between countries. The blue economy facilitates the transport of everything from food and fuel to construction materials, chemicals, and household items. Shipping carries $75 \%$ of Europe's external trade by volume and just over $50 \%$ by value. About $30 \%$ by tonne-kilometres of freight within and between EU Member States is carried by sea. These proportions have remained relatively constant overt the past 20 years. The percentages are typically higher for third world countries like Ghana. World seaborne trade has grown exponentially regardless of the global economic crisis and this is likely to continue. Littoral nations need to position themselves well in terms of port facilities and capacities to cater for this growing trade and optimize their benefits. Undeniably, shipping is the safest, most secure, most efficient and most ecologically sound means of bulk transportation with declining rates of accidents, improving turnaround of ships and significant reductions in discharges to sea or emissions to air. Much of these advances has been made possible because of the International Maritime Organization's regulations, industry initiatives and technological developments.

\section{Serves as a source of food and medicine}

Again, the blue economy is a source of food and medicine for the people at the seaside. Fish accounts for about $16 \%$ of the animal protein consumed globally. Even though human activities has directly and evidently reduced ocean productivity, the blue economy continues to feed the entire nation unequivocally with its various gifts of fishes. The reduction of ocean productivity may also be due to climate change increasing ocean stratification and reducing nutrient mixing in the open seas. Aquaculture is the fastest growing global food sector now providing $47 \%$ of the fish for human consumption. Fish used for human consumption grew by more than 90 million tonnes in the period 1960-2009 (from 27 to 118 million tonnes) and aquaculture is projected to soon exceed capture fisheries as the main provider of such protein. Aquaculture with fed species, if not managed properly, can affect biodiversity and ecological unit functions through extreme nutrient release, chemical pollution and the escape of farmed species and diseases into the natural environment. Growth in aquaculture sector in 
Asia, which accounts for more than $89 \%$ of global production, is more than $5 \%$ a year. In Ghana and some parts of Africa, the sea is medicinal aiding in the curing of some notable diseases like stomach pain, bacterial infections, digestion ailments, and even used to help fight liver and kidney problems. The medicinal benefits of the blue economy cannot be underestimated or ignored as it has help a lot especially the poor who could not afford the hospital form of treatment. The sea medicines sometimes proves more efficiently than the orthodox medicines. Aquaculture offers vast prospects for the provision of food and medicine to the citizenry of the nation, though inordinate efficacies in provision of feed to aquaculture need to be appreciated, including reduced fish protein oil and increased plant protein content, if the industry under the blue economy is to be sustainable.

\section{A source of tourism and recreational}

The blue economy also contributes to national development by serving as a source of tourism and recreational. Coastal tourism is a very important sector to the Ghanaian economy and many developing countries. Tourism and recreation is a major global industry that do not only bring revenue to the nation but also serves as a catalyst to that attracts investors into the country. Tourism has been a major support of global jobs and has generated trillion of dollars to the participants. International tourism has grown from 25 million in 1950 to 1,035 million in 2012 and further growth of 3-4\% in 2013 and the UNWTO further forecasted growth for 2030 to be around 1.8 billion. Tendencies in aging populations, rising incomes and relatively low transport costs will make coastal and ocean locations ever more attractive and lucrative. Vacation trip tourism is the fastest growing sector in the leisure travel industry; overall, average annual passenger growth rates are in the region of $7.5 \%$ and passenger expenditures are estimated in the order of US\$ 18 billion per year. The tourism consumer, however, is driving the transformation of the sector with a $20 \%$ annual growth rate in ecotourism; about six time the rate of growth of the overall industry. Higher education courses need to deliver a solid grounding in the specific skills needed to maintain and increase market share in a discerning and competitive global market.

\section{Energy and submarine mining}

Energy and Submarine mining is also another area where the blue economy provides its contribution to national development. Deep sea oil drilling is not new and has been in existence for long, but market pressures are making the exploration for and tapping of ever more remote reserves cost effective, bringing the most isolated areas under consideration. Oil will remain the dominant energy source for many decades to come but the Ocean offers enormous potential for the generation of renewable energy - wind, wave, tidal, biomass, and thermal conversion and salinity gradients. Of these, the offshore wind energy industry is the most developed of the ocean-based energy sources. Deep-sea mining has always been appealing and attractive to many countries of which Ghana is not an exception as a means of economic development and revenue generation. A Canadian company (Nautilus Minerals), and the Independent State of Papua New Guinea in April 2014 signed an agreement to begin the world's first deep sea mining for ores of copper, gold, and other valuable metals (Nautilus Minerals, 2014). Mining companies, and national governments, have leases to explore margin sediments for phosphates off Namibia, New Zealand, and Mexico (Mengerink et al., 2014) In Ghana, the agreement is with Tullow oil for the extraction of oil from the Ghanaian portion of the blue economy. Between 2000 and 2010, the price of many non-energy raw materials increased annually by about $15 \%$, mainly as a result of consumer demand in emerging economies (WTO, 2010). Advances in technology, as well as anxieties and unease over security of supply have encouraged mining companies to consider what the seabed can provide. By $2020,5 \%$ of the world's minerals, including cobalt, copper and zinc could come from the ocean floors. This could rise to $10 \%$ by 2030 . Global annual turnover of marine mineral mining can be expected to grow from virtually nothing to $€ 5$ billion in the next 10 years and up to $€ 10$ billion by 2030 (EC, 2012). All governments of the coastal countries needs to adequately prepare themselves to meet and solve marine challenges to ensure that, they amass substantial benefits from resources in their own exclusive economic zones, which will go a long way in contributing to national development 


\section{Recommendation}

The discussion above shows the strategic position of the blue economy in projecting the path of national development. Some of the dangers, which has submerged the blue economy in Ghana centers on over-exploitation, government's neglect of stringent marine policies, mistreatment and climate change. To address the perennial crises that has bedeviled the blue economy in Ghana, the blue economy should be a very solemn concern and responsibility of the government of Ghana at the same time, the private sector should be made to participate fully in its preservation. This will be successful if government on its part shows its seriousness and commitment to preserve the natural but great economic force of the nation. The article spoke about the contributions of the blue economy to national development and highlighted employment creation, tourism, trade facilitations and the likes as some of the contributions of the blue economy. Severe punishment should be meted to fishing folks who violate the rules and regulations of fishing the proper way as well as those security agencies who takes bribe in exchange of convicting pollutants of the marine life. Education of all stakeholders is very important in this regard and should be taken serious, as majority of our fishing community are not well informed about the dangers of their fishing practices to the blue economy. If the blue economy would be given a critical looked, it surely can be a driver for Ghana's economic benefit. Prudent management of the blue ocean has been identified as very important to accelerated national development. For this reason, successive governments must realize that reformation in blue economy policies and laws is a justification for judicious use of the economic force.

\section{Conclusion}

People living in coastal areas especially in African states have survived on the abundance of the oceans for many years and still lives on it because the coastal and marine environments provide important benefits to humanity. They supply fish, help regulate the environment, provide tourism attraction and facilitate the movement of goods, services and people. Fisheries alone provide several benefits to poor and needy coastal communities as well as being a major source of food to those communities and the nation as a whole. Fisheries provide employment for millions of people; both men and women in Africa alone. The extractions of resources from the marines contributes enormously to national development as well as it is a high revenue generation sector. However, in spite of the great benefits the blue economy possess, the importance and contribution of the blue economy is often underestimated and disregarded. This has led to overexploitation and degradation of the blue economy, reducing the quality and effectiveness of the benefits it provides. Nevertheless, if Ghana can focus and invest into the blue economy, the returns of its contribution to national development would startle all and sundry. The focus of this paper is the contributions of the blue economy to national development and the researcher has identified specific ways in which the blue economy contributes to national development. How the blue economy helps land lock countries to develop and the international roles of the God given resource are suggested areas of further studies.

\section{References}

[1].Catherine Piante/WWF-France (2013) The Strategic Meaning of "Blue Economy" Available at https://en.reset.org/blog/blue-economy-what-it. (Retrieved on $21^{\text {st }}$ April, 2017)

[2].Definition of "development" from the Cambridge advanced learner's dictionary \& thesaurus (C) Cambridge University Press. (Retrieved on $26^{\text {th }}$ April, 2017)

[3].Dr. Christian Bueger (2016), Maritime Security and the Blue Economy: Understanding the Link, available at http://www.westafricasecuritynetwork.org/maritime-security-and-the-blue-economy-understanding-the-link/ (Retrieved on $20^{\text {th }}$ April, 2017)

[4].EC, 2012. European Commission. Communication from the Commission to the European Parliament, the Council, the European Economic and social Committee and the Committee of the Regions: Blue Growthopportunities from the marine and maritime sustainable growth. COM (2012) 494.

http://eurlex.europa.eu/LexUriServ/LexUriServ.do?uri=COM:2012:0494:FIN:EN:PDF (Retrieved 28 April 2017).

[5].European Commission (2017), Staff working document on blue growth 2013-2016, Report on the blue growth Strategy towards more sustainable growth and jobs in the blue economy. Available at 
Texila International Journal of Management

Volume 3, Issue 1, Jun 2017

https://ec.europa.eu/maritimeaffairs/sites/maritimeaffairs/files/swd-2017-128_en.pdf (Retrieved on 28 ${ }^{\text {th }}$ April, 2017)

[6].Hiru Golam Rabbany (September 5, 2015), the Blue Economy - Opportunities in Bangladesh. Available on https://www.linkedin.com/pulse/blue-economy-opportunities-bangladesh-hiru-golam-rabbany (Retrieved on 29th April, 2017)

[7].http://www.mofa.gov.bd/content/about-blue-economy (Retrieved on $28^{\text {th }}$ April, 2017)

[8].Marine sustainability in an age of changing oceans and seas, Report by the European Academies' Science Advisory Council (EASAC) and the Joint Research Centre (JRC) of the European Commission EASAC policy report, 28 January 2016.

[9].Martin A. M. Gansinger, Ayman Kole (2017), Mapping Media Responsibility. Contemporary Aspects of Morals, Ethics and social discourse, Hamburg, Anchor Academic Publishing.

[10]. Micheli F, Halpern BS, Walbridge S, Ciriaco S, Ferretti F, Fraschetti S, et al. (2013) Cumulative Human Impacts on Mediterranean and Black Sea Marine Ecosystems: Assessing Current Pressures and Opportunities. PLoS ONE 8(12): e79889. https://doi.org/10.1371/journal.pone.0079889

[11]. Mengerink, K., Van Dover, C., Ardron, J., Baker, M., Elva Escobar-Briones, E., Gjerde, K., Koslow, J., Ramirez-Llodra, E., Lara-Lopez, A., Squires, D., Sutton, T., Andrew K. Sweetman, A., Levin L., 2014. A Call for Deep-Ocean Stewardship. Science 344, 696-698.

[12]. Nautilus Minerals, 2014. Nautilus Minerals and State of PNG Resolve Issues and Sign Agreement. News Release, April 14, 2014.

http://www.nautilusminerals.com/s/Media-NewsReleases.asp?DateRange=2014/01/01...2014/12/31 (Retrieved 28 April 2017).

[13]. Noone et al (Eds) (2012).Valuing the Ocean. Extended Executive Summary. Stockholm Environment Institute.

[14]. Sherman, K \& Adams, S. (Eds) (2010).Sustainable Development of the World's Large Marine Ecosystems during Climate Change. IUCN

[15]. The blue economy, growth, opportunity and a sustainable ocean economy. An Economist Intelligence Unit briefing paper for the World Ocean Summit 2015. Available at https://www.oceanprosperityroadmap.org/wpcontent/uploads/2015/05/2.-State-of-the-Blue-Economy_briefing-paper_WOS2015.pdf (Retrieved on $28^{\text {th }}$ April, 2017)

[16]. Tolu Lawal and Abe Oluwatoyin (2011) National development in Nigeria: Issues, challenges and prospects, Journal of Public Administration and Policy Research Vol. 3(9), pp. 237-241, November 2011, Available online http://www.academicjournals.org/jpapr. (Retrieved on 27 th April, 2017)

[17]. Thomas M. Leonard (2006), Encyclopedia of the developing world; volume 3.

[18]. UNESCO (2000). Education for All. New York.

[19]. World Tourism Organization (UNWTO), Annual Report 2013. Available at http://cf.cdn.unwto.org/sites/all/files/pdf/unwto_annual_report_2013_0.pdf (Retrieved on 27 ${ }^{\text {th }}$ April, 2017)

[20]. WTO, 2010. Trade growth to ease in 2011 but despite 2010 record surge, crisis hangover persists, PRESS/628, 7 April 2011. http://www.wto.org/english/news_e/pres11_e/pr628_e.htm (Retrieved on $20^{\text {th }}$ April, 2017)

[21]. WWF Global Report (2015), Reviving the ocean economy; the case for action. Available at http://wwf.panda.org/what_we_do/where_we_work/coraltriangle/publications/?245010/REPORT-Reviving-theOcean-Economy-The-case-for-action---2015. (Retrieved on $20^{\text {th }}$ April, 2017) 